\title{
Digital Reconstruction of the Akhenaten Torso in the Brooklyn Museum
}

\author{
MATEI TICHINDELEAN, Indiana University, USA
}

The Torso of Akhenaten in the Brooklyn Museum is an excellent example of Amarna style sculpture-an artistic technique employed during the reign of the "heretic" pharaoh Akhenaten. This study uses photogrammetry to render an accurate 3D state model and a subsequent reconstruction model intended to help address questions regarding the nature of worship centered on the Aten. The reconstruction is based on theological and royal iconography specific to the Amarna period. It sheds light on the religious reorganization of the New Solar Theology and aims to facilitate a better understanding of the role of royal statuary in the context of an Egyptian temple.

\section{Key words:}

Photogrammetry, Egyptology, Amarna, Akhenaten, Royal Statuary.

\section{SDH Reference:}

Matei Tichindelean. 2019. Digital Reconstruction of the Akhenaten Torso in the Brooklyn Museum. $\mathrm{SDH}, 3,1,16-39$.

DOI : $10.14434 /$ sdh.v3i1.27179

\section{INTRODUCTION}

The Torso of Akhenaten (inv. No. 58.2) in the Brooklyn Museum is displayed in the section of the museum dedicated to the art of the Amarna Period. It stands somewhat larger than life at $21 \times 13 \times 16$ in. $(53.3 \times 33 \times 40.6 \mathrm{~cm}$ ). As with many statues typical of Akhenaten's reign, the collarbones are accentuated and meet up symmetrically, joining with the sternocleidomastoid muscles. On his chest are three inscribed cartouches. Another less legible one is found on the lower left side of the back. This incomplete cartouche allows us to date the sculpture to Akhenaten's first nine regnal years (i.e., ca. 1370-1360 B.C.E.) [Cooney 1965:102]. Around the torso's waist are clear traces of a sash and pleated skirt, which is a common feature of most sculptures of Akhenaten. The torso is supported by a pillar which runs half way up its back and slopes towards the neck imitating a wide flaring braid. The partially destroyed statue was found by W. M. Flinders Petrie during the 1891-2 excavation season at Tell El-Amarna in a trench on the south-east side of the Great Temple. It then became part of Lord Amherst's collection until 1921, when it was sold together with a variety of other Amarna period pieces. It remained in the Arthur Sambon's collection in Paris until it passed to the auction house of Kalebdjian Frères. In 1936 it was offered to the Brooklyn Museum for \$2,000, an amount that was deemed too expensive [Cooney 1965:102]. Subsequently, it was bought by a French collector [Cooney

\footnotetext{
The work of this project has been carried out in cooperation with the Brooklyn Museum (New York, USA).

Author's address: Matei Tichindelean, Department of Near Eastern Languages and Cultures, Indiana University, Global and International Studies Building, 355 N. Jordan Avenuel Bloomington, IN 47405-1105; email: mtichin@iu.edu.

(C) [2019] by the author; licensee Studies in Digital Heritage, IU, Bloomington (IN), USA. This article is an open access article distributed under the terms and conditions of the Creative Commons Attribution License (CC BY-NC).
} 
1965:102], and it finally came into the Brooklyn collection most likely with the aid of the Charles Edwin Wilbour Fund, an endowment established in 1932 to support the museum's purchase of Egyptian antiquities.

\section{PREVIOUS PUBLICATIONS AND GOAL OF THIS PAPER}

W. M. Flinders Petrie paid little attention to the Brooklyn torso, limiting himself to the following description: "most of torso with Aten Names. Over life size. Medium stone and work." [Petrie 1894:18]. We can trace its accession into Lord Amherst's collection in 1921 [Griffith.ox.ac.uk 1921] and its mention by Arthur Sambon, who photographed it in 1931 [Sambon 1931:Pl. III]. In his brief overview of the objects at his disposal, he dedicated a paragraph to this torso and to the art movement it represents, incorrectly identifying the writing on the lower back as "Khou-en-aten" [Sambon 1931:18]. The most extensive publication discussing the Brooklyn torso was written by John D. Cooney, who expressed his thoughts on the object in his comprehensive catalogue of Amarna objects present in American collections [Cooney 1965]. Cooney's three photographs beautifully illustrate the distinct Amarna-style features of the statue. His concise discussion provides the reader with the necessary tools to appreciate this distinctive style and suggests a few hypotheses about its original reconstruction, although Cooney does not commit to a particular theory. In their 1968 introductory manual Egyptian Hieroglyphs for Everyone, Scott and Scott used a photograph of the Brooklyn torso to demonstrate the vengeful acts of the Amun priesthood following the death of Akhenaten [Scott and Scott 1968:84]. T. G. H. James concentrated on the reconstruction of the hieroglyphic cartouches on the torso's chest and back side. There is little doubt about the inscribed, and later defaced, Akhenaten name forms (Fig. 5A and B) [James 1974:135]. In Akhenaten and Nefertiti, Cyril Aldred provided precise measurements for the torso and its breaks, and briefly discussed the mutilations and damages done in antiquity [Aldred 1973:92]. Like Cooney before him, Aldred also provided two tentative reconstructions of the statue.

Most of the literature surrounding statues of Akhenaten concentrates on the theme of the artistic and religious revolution associated with his reign. Even though there are many art-historical discussions about the theological implications of Amarna art, the questions that this paper attempts to answer focus mainly on royal statuary and more specifically the cultic purpose it played in ritual activity. Therefore, key questions need to be addressed and explored before the restoration process can properly commence. What was the intended audience for this type of statuary? Where was the statue originally located? What role did the statuary serve? Possible answers will be presented illustrated by an accurate 3D model of the current state of the statue, rendered using photogrammetry. After these preliminary issues have been settled, the Brooklyn torso will be digitally restored in order to present the range of possibilities concerning its original condition and then reintegrated into its original context in order to better understand how it functioned.

\section{PROVENANCE AND CONDITION}

As mentioned, the torso was found in the 1891-92 excavations of W.M. Flinders Petrie near The Great Temple at Amarna. Petrie did not provide a specific find spot, nor did he provide details about the cache of sculptures that were found along with it. In fact, Petrie devoted more words to describing 
the clearance of the Great Temple undertaken by Howard Carter and the scarce results of his excavation [Petrie 1894:18]. The Great Temple complex was dedicated to the Aten, the newly established principal god (Fig. 1). The foundations of the temple excavated by Carter revealed an enormous temple complex with broad, open-air spaces. Its location near the palace and in the city's center emphasized the pharaoh's personal relationship with the Aten. Here, the sun disk, would be worshiped in front of hundreds of offering tables and mudbrick altars in a new religious and architectural environment. The temple was oriented to imitate the solar trajectory on an east-west axis with its main entrance on the Royal Road. The front of the enclosure was secured by a large pylon, where one would enter the House of Rejoicing. From there, a pillared hall led to a series of large open courts filled with offering tables. The only other building in the enclosure also consisted of open courts with offering tables.

Tomb reliefs show that statues of the king and queen were placed throughout the temple in various poses mimicking the daily offering rituals of the cult. Seventeen limestone fragments of the king and queen, which were found just outside of the temenos wall, south of the temple [Petrie 1894:18], add gravitas to such a depiction.

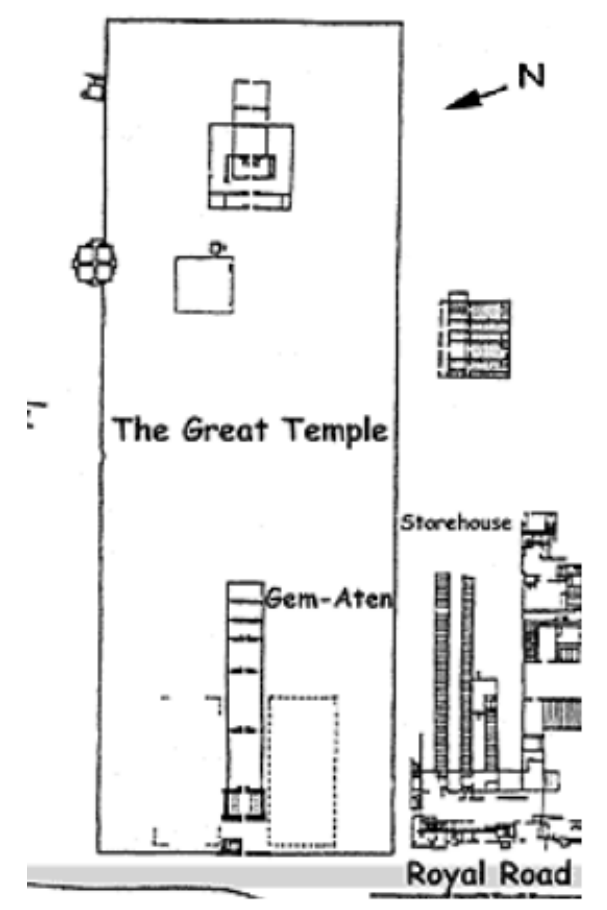

Figure 1. Great Aten Temple (Grandorge).

Petrie describes the Brooklyn torso in his list of the seventeen objects as: "Cap, 2 bits head, most of torso with Aten names. Over life size. Medium stone and work." [Petrie 1894:18]. He was evidently not too impressed with the craftsmanship of the sculptures. It is very important to note the reported position of the find, though somewhat imprecise. Also significant is the fact that the torso was buried together with more than 16 other fragments of life-sized statues, and the notation of " 2 hands with 
an offering slab" [Petrie 1894:18] is indicative of the spot where the statues originally stood. These clues help piece together the fate of the statue, its original context and position, all of which are critical components of any restoration.

The Brooklyn torso (Fig. 2) is carved out of white crystalline limestone. The original statue would have probably been assembled with several interconnecting parts; however, the torso is carved out of one block of limestone and given a matte finish. Studies of the Thutmose's workshop at Amarna and the various techniques used by sculptors during this period suggest that particular elements of sculptures were created separately by different artists and perhaps even by different workshops [Bodziony 2007:2-3]. It is highly likely that the Brooklyn torso was one such composite statue, especially since composite sculptures "allowed a considerable compensation of weight and therefore a reduction of the back pillar" [Bodziony 2007:3-4]. The torso's back pillar stretches only halfway up the back. Connected to the pillar seems to be what Cooney and Aldred interpreted as the wide flaring braid found on the bag wig [Cooney 1965:102] or afnet headdress [Aldred 1973:92].

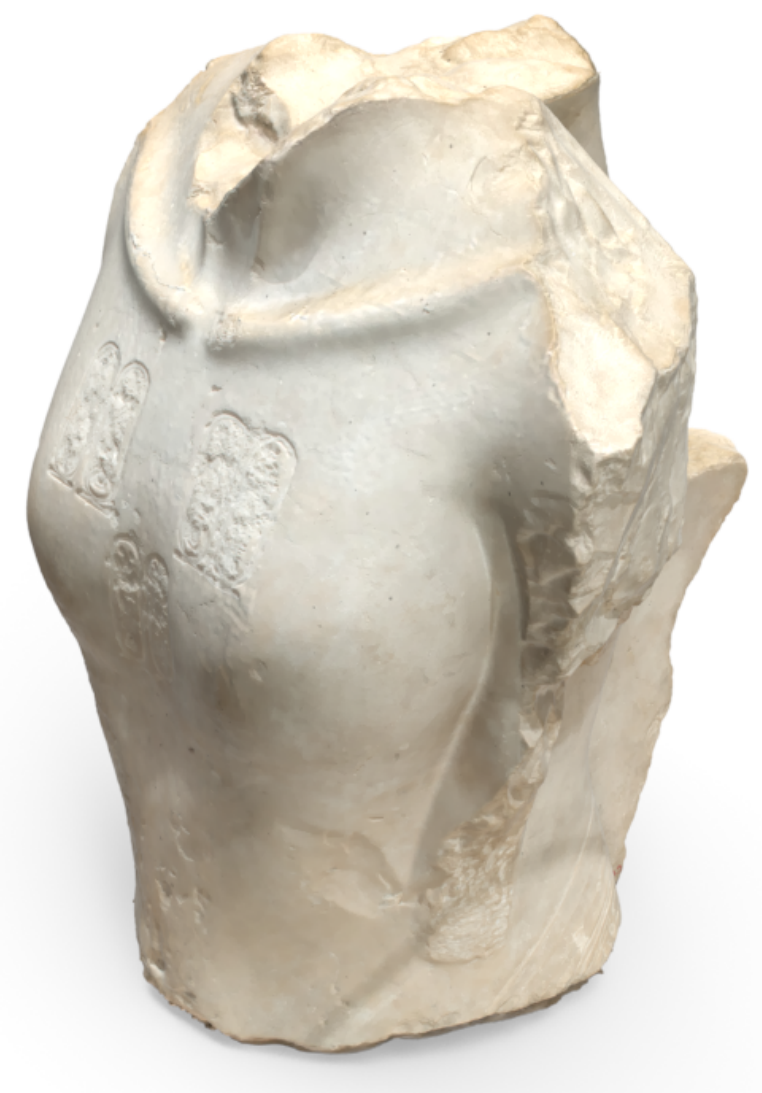

Figure 2. Brooklyn torso state model

There is little doubt about this interpretation, and the restoration model should be created to reflect this fact. The "bag wig" is referred to as the khat crown by most Egyptologist because of its specificity to this period in Egyptian history, whereas the term afnet occurs sporadically from the Old Kingdom 
through the Graeco-Roman Period and clearly is a more general form [Eaton-Krauss 1971]. The neck is partially intact, and it is therefore possible to identify its accentuated length, which is a characteristic motif in representations of Akhenaten. The two arms seem to have been chopped off; however, there is evidence that the arms were joined to the torso as far as the elbows. The lower part of the torso was broken off slightly above the hips. The three sets of cartouches bearing Akhenaten's Aten names have been carefully effaced by being chiseled out, however the lower pair still displays some hieroglyphics. On the lower right side of the back of the torso, part of a cartouche bearing an early form of the Aten name is still visible. The calculated destruction of the torso seems to have occurred in two phases: the first phase involved the careful chiseling out of the chest cartouches (which most likely occurred right after his death); the second one involved the deliberate smashing of the statue and its burial most likely at the direction of Ramesses II [Cooney 1965:106]. Aldred believed that this second phase coincided with the Ramesside destruction of the Great Temple, which was motivated by the desire to reuse the statue's pedestal stone [Aldred 1973:92].

\section{CONTEXT, PURPOSE, RESTORATION}

The Great Aten Temple at Amarna is located in the Central City, the heart of the new administrative and religious center established by Akhenaten. It was an enormous building project, with a rectangular brick enclosure measuring $800 \mathrm{~m}$ by $300 \mathrm{~m}$. As mentioned earlier, the complex only included two stone buildings, one designated as the Gem-pa-Aten (more commonly known as the Long Temple) (Fig. 3) located towards the entrance of the whole enclosure, and the other one, named the Sanctuary, is located toward the rear. Immediately to the south of the Long Temple, 920 mudbrick altars were laid out in a grid pattern. It has long been speculated that the original complex might have contained more buildings and probably an equivalent "field" of offering tables on the north side of the Long Temple, however modern agricultural and mortuary intrusions seem to have destroyed most evidence. Within the Long Temple a series of monumental pylons divided open courts containing at least a total of 791 offering tables [Amarna Project].

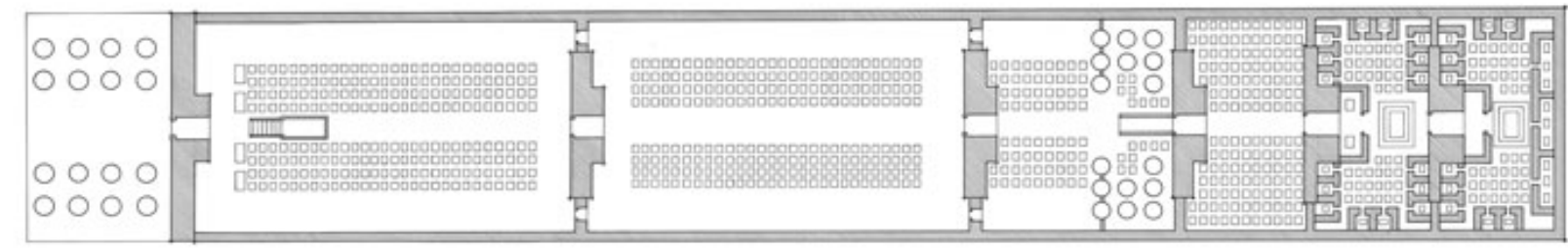

Figure 3. Reconstruction of the Long Temple (Amarnaproject.com).

The Sanctuary (Fig. 4) was a much smaller building with two open courts divided by a monumental pylon. Within, one could find the same layout of open courts filled with offering tables. A few distinctive features were identified within this temple, including so-called "purification rooms," slaughtering courts, and according to some tomb reliefs referencing the temple, a possible platform for a round-topped stela evocative of the Aten [Amarna Project]. The reconstructions in Figs. 3 and 4 are based on the synthesis of archaeological evidence and depictions of the surrounding noble and royal tombs compiled by N. G. Davies in the early 1900s. The same depictions combined with 
analogous examples from Amarna and Akhenaten's temple in Karnak have provided us with the necessary evidence to justify the restoration presented here.

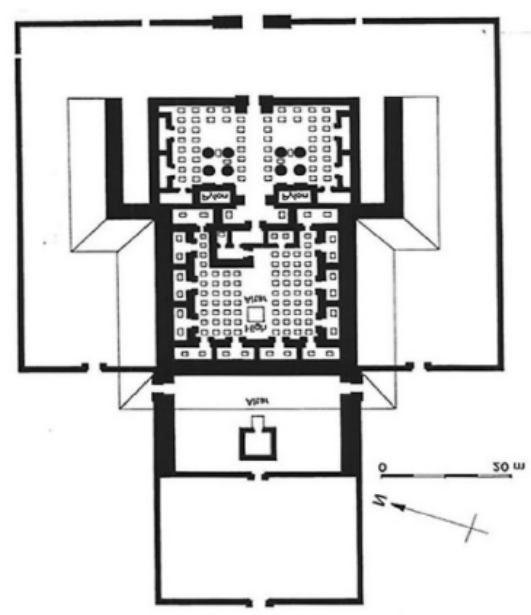

Figure 4. Reconstruction of the Sanctuary (Amarnaproject.com).

This was the religious center from which the Atenistic religion was promulgated throughout the empire. The Aten's iconography and identity as a divine king who ruled the world was firmly established by Akhenaten [Hornung 1999:54]. In this respect, Akhenaten became his son (unlike previous pharaohs who considered themselves to be the "son of Re"). Assmann cogently summarizes as follows the establishment of the new religion and the cognitive change that occurred during the Amarna period: "the New Solar Theology arose as a cognitive iconoclasm that rejected the entire mythic, pictorial world of polytheistic thought. It confined itself strictly to visible reality. All its basic principles can be understood as theological explications of cosmic phenomena, specifically the sun, its light, and its movement" [Assmann 2001:201]. This implies not only the need to eliminate all other divinities, but also a new form of worship which had to be devised. The sun's uniqueness is thusly emphasized, and it is decreed:

(The Aten) Who builds himself with his own arms,

artists do not know him. [Sethe 1909].

The god could only be represented and worshiped "in a constellation with the royal couple" [Assmann 2001:209]. In contrast with the art of earlier and later periods, where an adored statue of the god stood at the center of cultic worship, Akhenaten's new religion used the triad comprised of the solar disc, himself, and Nefertiti as the divine cult statue [Robins 1997:150]. Akhenaten often portrayed himself as the living manifestation of the deity [Robins 1997:149], not only making offerings to the solar disk but also receiving offerings from his subjects. Thus, the Great Temple became a mechanism for the continuation of the cosmos and the maintenance of the divine order. The role of Akhenaten as a demigod mediating between the divine and earthly realms was closely guarded in iconographical representations behind the high walls of the complex. The architecture had to be adjusted. The doorways sported broken lintels, the processional way and the columned halls were open to the sky, and every effort was put into avoiding shadows [Hornung 1999:73]. Everything was done in order to 


\section{2:22 M. Tichindelean}

allow for the king to be in direct contact with the Aten. In this sacred temple, the royal family and a few specialized priests were the only ones allowed to enter and worship the Aten.

The nobility and the priestly strata of Egyptian society were completely reimagined with the advent of Atenism. It seems that the interaction of non-royals with the omnipresent god was severely restricted. Depictions from the tomb of police chief Mahu have him kneeling before a heap of offerings praying to the Aten for the king's health while situated outside the great temple in front of the closed pylon [Hornung 1999:76]. While in previous ages, a person's moral behavior determined his passage into the afterlife, the new religion called for adoration and obedience to the king [Teeter 2011: 479]. Even the concept of the afterlife changed. Most noble tombs in the Amarna necropolis have the single theme of worshipping the king: "How prosperous is one who carries out his teachings, for he shall reach the district of the favored ones (i.e. necropolis)" [Mundane 1995:119]. This "brokered" worship of the Aten had to be supplemented in the theological context by statues and depictions of the king fulfilling his duty as provider of offerings. Innumerable statues of the royal couple filled the sanctuary and the empty spaces between the columns. The statues representing the king in a theological context often show Akhenaten as the manifestation of the Aten on earth-the human guise of the Aten [Manniche 2000:105].

The discovery of the torso in such close proximity to the temple complex leaves little doubt as to the original position of the statue and its intended purpose. Such statues representing the reigning king, or a personification of his image as a deity, are not specific to the Amarna Period but are common throughout dynastic Egypt. Akhenaten's father, Amenhotep III, started the trend, and it continued well into the Ramesside period [Kozloff et al. 1992]. Many sovereigns show their divine right to rule through close associations with a certain deity in a religious context. In such cases, "official portraits inform the viewer how the ruler wishes to be regarded" [Kozloff et al. 1992:125]. Akhenaten was no stranger to this. In fact, Walther Wolf suggested that such statues might be a mechanism for Akhenaten to portray himself as an "ecstatic, almost monstrous, transformation (Formverwandlung) [Wolf 1957:453]." Although in this case Wolf was referencing the colossi of Akhenaten discovered at Karnak, this Formverwandlung is often employed by Akhenaten in order to portray himself as the Aten. To the Egyptians, Akhenaten's image within this context would be seen as divine or, at least, as representing someone in the act of worship [Kozloff et al. 1992:126]. The fragmented cartouche on the torso's lower back side denotes one of the Aten names, namely the one associated with Shu. The still visible hieroglyphics read $\mathrm{n}$ ? $\mathrm{w}$ nty $\mathrm{n}$ 'Itn, which corresponds to the last part of the appellation name: "(Re lives, Har-akhty, who rejoices on the Horizon in his name) 'Shu, who is Aten'" (Fig. 5B). In accordance with the studies of Williams, who examined another closely related torso from Amarna (now in the Metropolitan Museum of Art) bearing the same inscription, we can date our torso somewhere between 1369 and 1366 BCE, meaning between Akhenaten's 6th and 9th regnal year [Williams 1930:84]. Cyril Aldred's study of the development of the Amarna Style suggests that the torso, along with the statue in Figure 13, date to the transitional period of the artistic styles of the Early Period and Late Period [Aldred 1973:57]. Aldred goes on to credit the sculptor, Bek, active at Amarna, as the artist behind these sculptures found by Petrie and Carter in 1891 [Aldred 1973:57]. As Bek is believed to have died before Akhenaten's ninth regnal year, he narrows down the date to Year 8, during an artistic transitional period sparked by Bek's death [Aldred 1973:57-58]. This Formverwandlung and attribution of god names intermixed with the King's epithets are employed 
so often during Akhenaten's reign that it is often very hard to distinguish between a representation of the king in his human guise and in that of the god. In our case, the torso's size and the cartouches are more indicative of a representation of a human being.

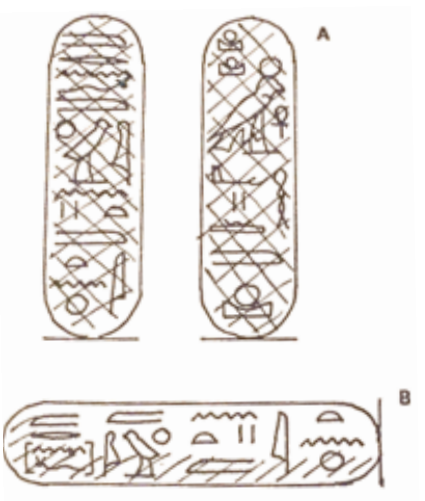

Figure 5. Reconstruction of Aten names on the chest (A) and on the lower back (B) [James 1974].

The purpose of such statues within the temple complex is not only dependent upon the royal iconography but also its pose and location. Therefore, at this point, it is crucial to consider one of our earlier questions: what is the intended audience? It is here that we must carefully consider Stephen Renton's warning about equating our modern concept of an audience with that of the ancient Egyptians: "we need to consider not only a possible contemporary audience (e.g., members of the priesthood, administration, maybe even the gods), but more importantly a 'future' audience in the context of ancient Egyptian temples" [Renton 2008]. Although his argument centered around discussions with respect to monumental inscriptions and wall scenes, it is certainly transferable to statuary. Our statue was obviously intended for Amarna's contemporary audience: the royal family, the few members of the Aten priesthood, and perhaps some of the most beloved courtiers (considering that individuals such as Huya have representations of these statues in their tombs). However, we must also seriously consider the iconographical aspect of such an object, or indeed any messages present in these sacred spaces. In this regard, Renton proposed that the intention might resemble Brunner's canonization argument and the institutionalization of permanence [Renton 2008]-in our case cementing the theological ideas of the Aten cult and Akhenaten's kingly role. In theory, the idea of institutionalization of permanence put forth by Renton and by Brunner before him offers a solution to the problem regarding the strictly selective access to the temple. Renton argued that if something such as a divine birth scene is carved onto a temple, then, according to the ancient Egyptian beliefs, it immediately enters the "cosmos" and becomes eternal [Renton 2008]. Therefore, the debate about access to the depiction, or, in our case, the statue, becomes a moot point. Egyptian theology immediately attributes living, cosmic force to statues and depictions located within the sacred boundaries of a temple. The destruction of the torso, and its removal and burial outside the temple temenos, not only dooms the monuments of Akhenaten, but also his living presence in the cosmos. 


\section{RECONSTRUCTION}

Our statue's purpose is not only defined by its theological implications but also by its pose. The bestpreserved Akhenaten/Amenhotep IV statuary found buried in to date are the colossi found in his Aten sanctuary at Karnak. While these colossi are fashioned in the early Amarna style (in the first four years of his reign) [Manniche 2000], they represent concrete archaeological evidence which coincides with pictorial evidence found in elite tombs at Amarna. These colossi and their placement in the Karnak temple are crucial in reconstructing the context of Akhenaten statues within Aten temples. As these statues served as representations of the king, during his absence, they acted as physical representations of the king engaging in ritual activity. The restoration of the Brooklyn torso was based on two primary sources of evidence: (1) the physical evidence on the torso which escaped destruction, and (2) the epigraphic surveys of the Amarna tombs.

The torso displays clear evidence that the arms were connected to the torso up to the elbows (see state model Fig. 2). This indicates two possible solutions, as corroborated by Cooney [Cooney 1965:102] and Aldred [Aldred 1978:92]: the original torso was holding an offering table similar to representations in Figure 6 or presenting a stela similar to the small statue in Figure 7 . One of our proposed restorations was strongly influenced by the hitherto overlooked offering table fragments found with the torso. The "2 hands with an offering slab" [Petrie 1894:18] recovered from the same pit and bearing Akhenaten's name might have well been part of the same statue as the torso.

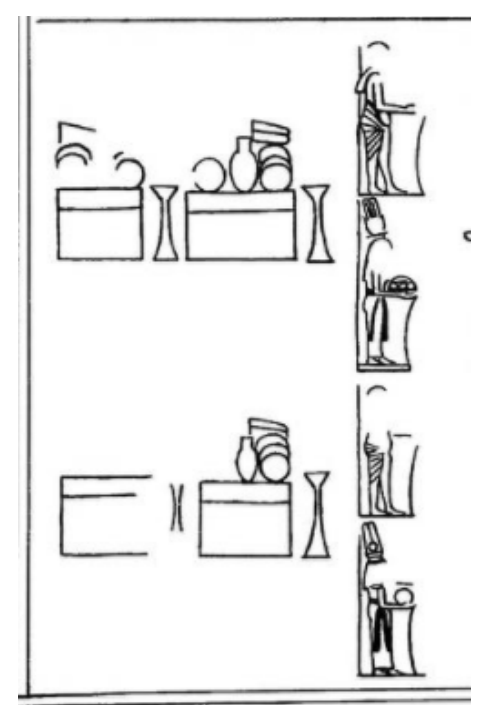

Figure 6. Representations of offering statues of the king in the Inner Sanctuary from the Tomb of Huya [Davies 1905b] 


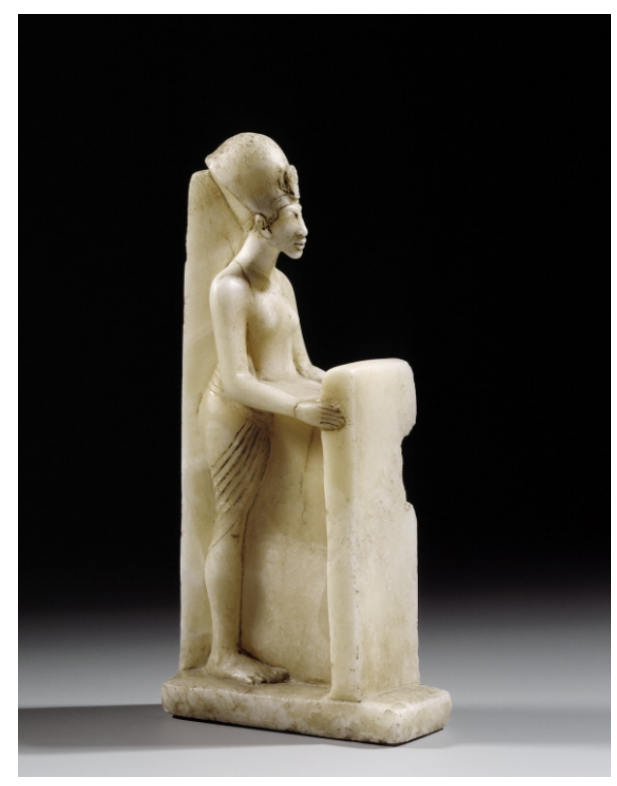

Figure 7. Standing figure of Akhenaten holding a stela (Ägyptisches Museum und Papyrussammlung der Staatlichen Museen zu Berlin).

a)

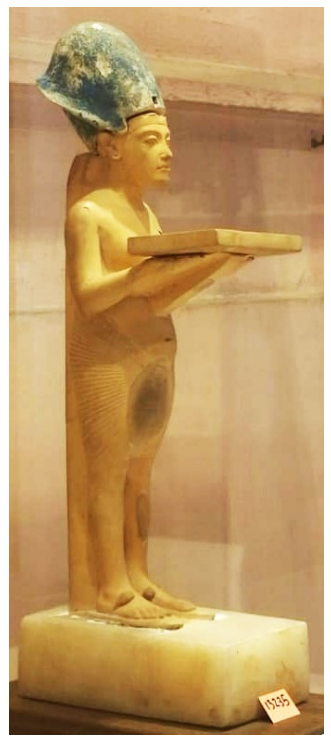

b)

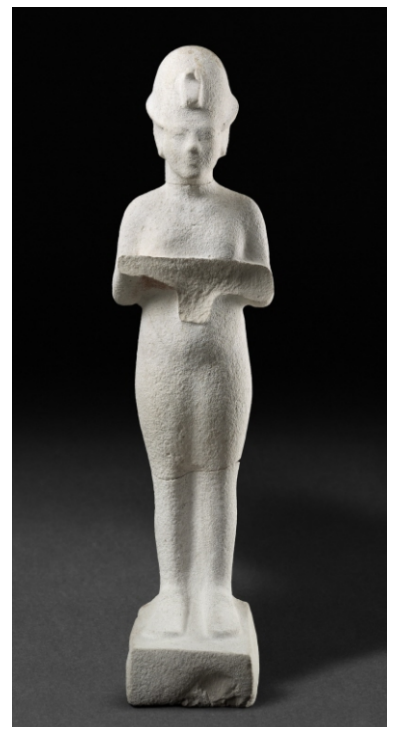

Figure 8. Akhenaten sculptural representations: a) Akhenaten with offering table in Cairo Museum (Photo credit: Amr Adly); b) unfinished offering statue of Akhenaten (̈̈gyptisches Museum und Papyrussammlung der Staatlichen Museen zu Berlin). 
In addition, the sheer number of representations in tomb reliefs of offering statues around the Aten temple heavily outnumber the ones of the pharaoh holding a stela. The remaining joints attached to the torso and used to support the arms from shoulder to elbow may indicate that this offering pose would have been a likely purpose of this statue. Similar statues unearthed at other Amarna excavations offer parallel examples (Fig. 8). While some are similar in size to the Brooklyn torso, there are many examples of statuary small enough to be used in household shrines (Fig. 8). There is a significant feature of all the surviving offering statues of the Amarna period that needs to be addressed: the triangular support that connects to the statue's belly in order to provide extra support for the offering platform. This feature (evident in figure 8) was also addressed by Cooney, who pointed out that the lack of evidence of such a support provides difficulties in developing a reconstruction [Cooney 1965]. However, a short discussion about ritual offerings involved in the cult of the Aten could provide a remedy for the lack of such a support in our case.

While the abundance of altars in the courtyards of the temple is indicative of mass sacrifice of the traditional cattle and geese, the preferred offering to the sun disk was flowers [Hornung 1999:73-74]. This tendency appears to become popular early in Akhenaten's reign, as evidenced in inscriptions in Ramose's tomb in Thebes. Here, Ramose appears before Amenhotep IV, enthroned next to the goddess Maat, accompanied by the texts: "Words spoken by the city overseer and vizier Ramose, justified: 'For your Ka, the bouquet of your father (...)'" [Murnane 1995:62]. This ritual offering is extensively present in ritual scenes of Akhenaten and Nefertiti at Amarna. In the Amarna tomb of First Servant of the Aten, Panehsy, he is shown together with Akhenaten and the queen offering flowers to the Aten. Their first four royal daughters are also shown holding bouquets (Fig. 9).

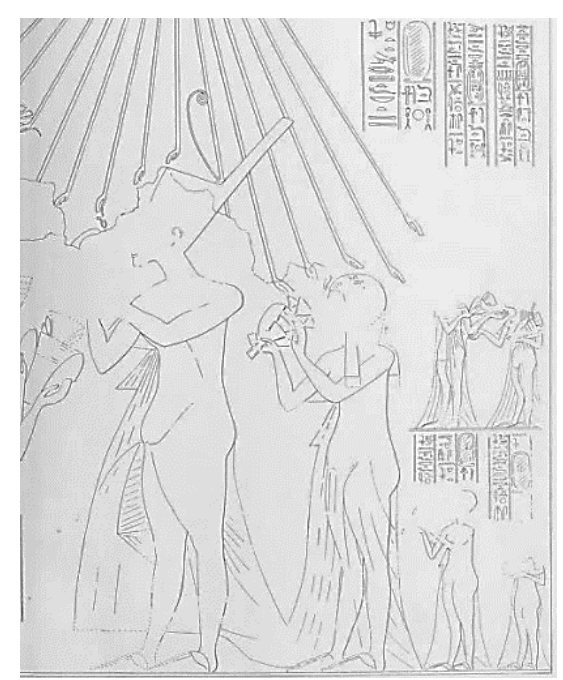

Figure 9. Akhenaten and the royal family offering flowers to the Aten [Davies 1905a].

The inconsequential weight of flowers does not necessitate the extra support for the offering table. Furthermore, images of Akhenaten offering statues often show them positioned in front of or just above altars, as if the pharaoh is about to place the offerings onto the mudbrick structure (see Fig. 6). Since offering tables themselves together with the magical inscriptions replaced the physical offerings, it is reasonable to conclude that the offering table held by the Brooklyn torso did not need 
to support the weight of any offerings and therefore had no need of a protruding triangular support. An alternative solution is explained by images of offering statues (Fig. 6) who appear to use mudbrick altars to stabilize and maintain the integrity of the bent arms and provide additional support for the offering table, similar to what the triangular support was intended for. These mudbrick altars would have been plastered with mud and coated in white [Kemp and Bertram 2018:3], blending it seamlessly into the offering table. However, this argument is rather unconvincing as there is a lack of archaeological evidence and we are forced to rely only on Davies' facsimiles.

Although the second suggestion introduced by Cooney and Aldred, of the arms bent at the elbows and presenting a stela is a possibility, the lack of parallel examples is of serious concern. The $12.2 \mathrm{~cm}$ high statuette in the Ägyptisches Museum und Papyrussammlung der Staatlichen Museen zu Berlin (Fig. 7) is the only known complete archaeological example. Its small size and the fact that there is no negative space between Akhenaten and the stela diminishes the probability of this reconstruction. Recent removal of spoil heaps from Pendlebury's excavations allowed Marsha Hill to attribute two isolated fragments to a "life-size or slightly smaller statue" that held a high pillar (a stela) similar to the ones that were present at the city's Boundary Stela in Fig. 10 [Hill 2018a:15-17].

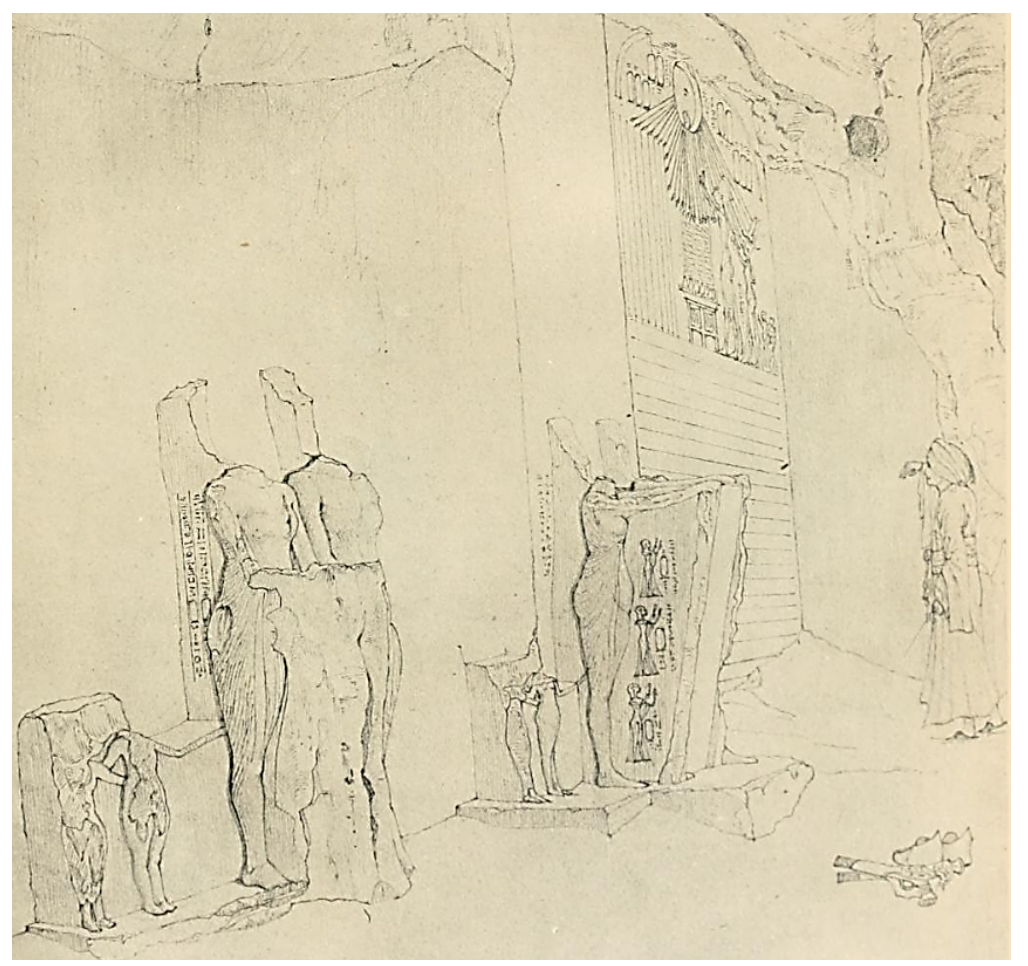

Figure 10. Boundary Stela Statuary. Drawing by Robert Hay, 1827 [Davies 1908:Plate XLIII].

However, the Boundary Stela type statuary presents the same problem as the example in Fig. 7, namely that the stela is connected to the body all the way from the statue's feet to the midsection or upper body. While we should not dismiss the lack of archaeological evidence as evidence of absence, it is hard to argue for such a representation given the lack of definite supporting data. Perhaps the 
most compelling argument against such reconstruction is the lack of pictorial evidence. The corpus of depictions of the Great Aten Temple recorded in the Davies's epigraphic surveys do not show any clear examples of such statues.

Among the alternatives presented here, a representation of Akhenaten sitting on a throne merits substantial examination. While no examples from the Amarna Period survive, the epigraphic surveys coordinated by Davies do depict such a statue present within the Great Aten Temple (Fig. 11).

Additionally, two recently analyzed fragments are presented by Marsha Hill as belonging to a seated statue [Hill 2018b:62, 84]. A decorated limestone fragment in the Metropolitan Museum of Art 21.9.579 bears motifs often depicted on thrones, while a small fragment from the San Diego, Museum of Man 14945D (TA 26A/142) indicates a hand positioned "at the edge of a standard Amarna royal kilt" belonging to a royal seated statue [Hill 2018b:62]. Renditions of the king on his throne are extensively attested throughout Egyptian history, the pose being extensively utilized during the reign of Akhenaten's father, Amenhotep III.

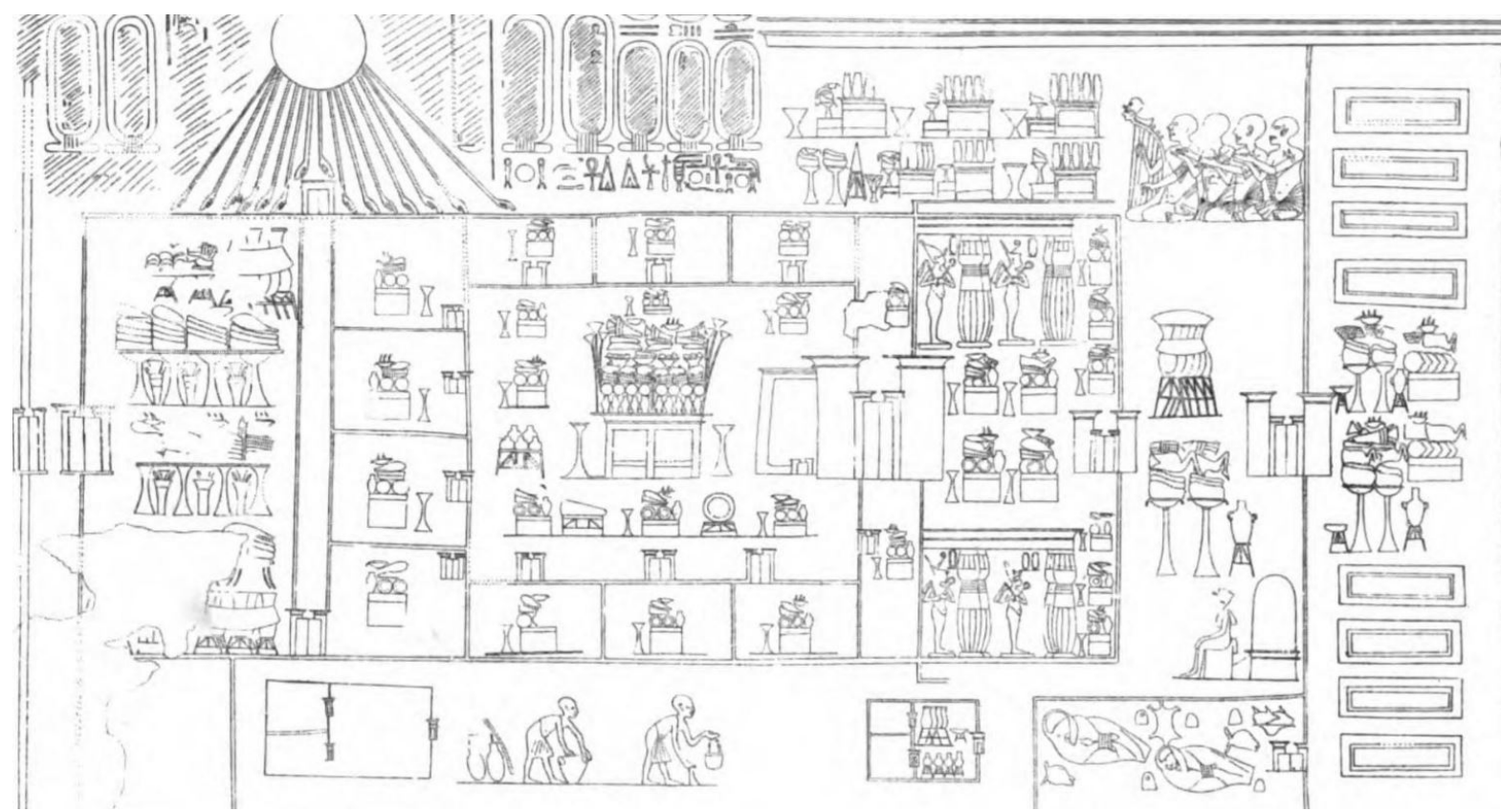

Figure 11. Scene depicting a seated king statue in front of a stela from the Great Aten Temple (from the tomb of Meryra in Davies 190, North Wall).

The relatively complete colossal statue of Amenhotep III from the British Museum (Fig. 12) can be used as a close parallel. Within the temple environment the statue functioned as a recipient of offerings and while the king might appear inactivate, the rebus evokes royal symbology associated to the goddess Isis and the king represented as Horus-divine son of Isis [Kozloff et al. 1992:130]. There is little doubt that the early artistic style of Akhenaten was influenced by Amenhotep III's vast statuary repertoire [Kozloff et al. 1992; Manniche 2000; and Hornung 1999], and while there are no over-lifesize seated statues of Akhenaten that have survived, the fragmentary evidence discussed by Hill [Hill 2018b:53-85], combined with Davies' epigraphic evidence merits serious consideration 
concerning the possibility of the Brooklyn Museum Torso being part of a seated statue. Unfortunately, due to a lack of access to a comparable model, no digital reconstruction of the seated pose is present in the current paper. However, a forthcoming publication by the author will explore a multitude of possible digital reconstructions of the Brooklyn Museum Torso. In an effort to keep within the scope of the current discussion, I will be focusing on the evidence pertaining to the offering pose statue.

The reconstruction of the Brooklyn torso in the offering pose leads us to the question of its placement within the temple complex. Once again, we must rely on depictions and comparison to the Karnak colossi. Although on a much grander scale, the Karnak colossi have a "pillar" construction similar to that of the Brooklyn torso. Christian Leblanc noted two distinct uses of "pillar statues:" (1) actual pillars combined with sculptures supporting architraves (found in courtyards, terraces, halls in rockcut temples, and facades), and (2) where the pillar element supports the statue, not an architrave or the like (found along causeways and walls of a court or hall, in front of gates or pylons, in niches and kiosks) [Manniche 2000:91]. Leblanc's typology implies that the Brooklyn Museum torso fell in the second category, placing the original statue in a courtyard or causeway of the Great Aten Temple.

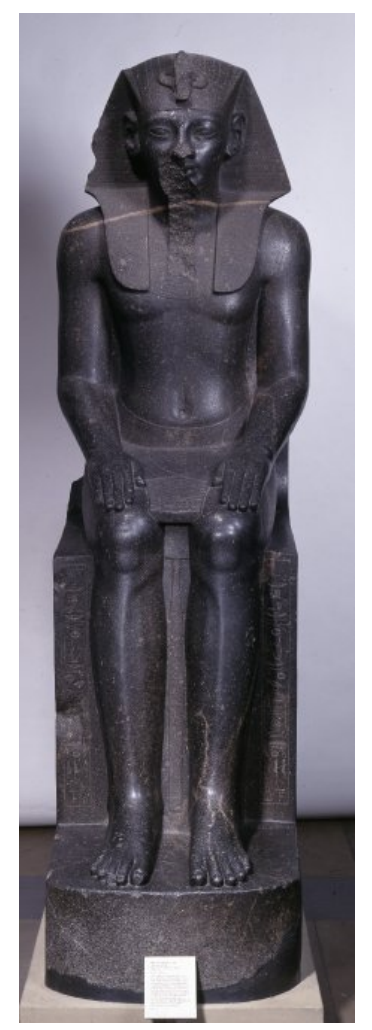

Figure 12. Seated statue of Amenhotep III (The British Museum 2018)

Cooney suggests the original position of the statue was between columns on one side of the Sanctuary as evident in reliefs from the tomb of Huya [Cooney 1965:106]. While he does not specify exactly to which reliefs he was referring, I believe he had in mind the representations of the king and queen in Figure 13, because he argued for a reconstruction of the arms holding an offering table. 


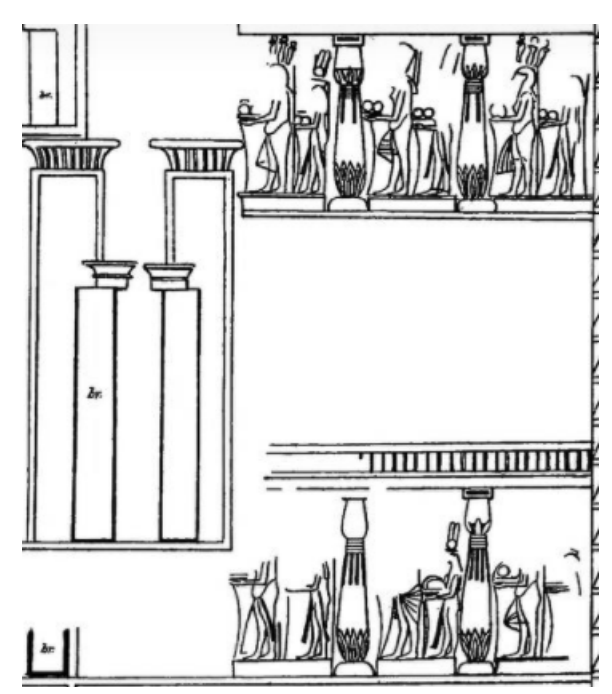

Figure 13. Statues of Akhenaten and Nefertiti in offering poses from the Great Temple [Davies 1905b].

However, a close inspection of the Davies facsimiles, reveals that the back pillar stretches all the way to the crown of the king and queen, a feature not present on the Brooklyn torso. In addition, the blue crown headdress the king is wearing does not possess the same widening characteristic of the khat crown Cooney mentioned earlier [Cooney 1965:102]. Consequently, Cooney's contradiction gives way to only one option, supported by epigraphic evidence from Huya's tomb (Fig. 6) and a fragmentary block found at Hermopolis (but originally from Amarna) (Fig. 14).

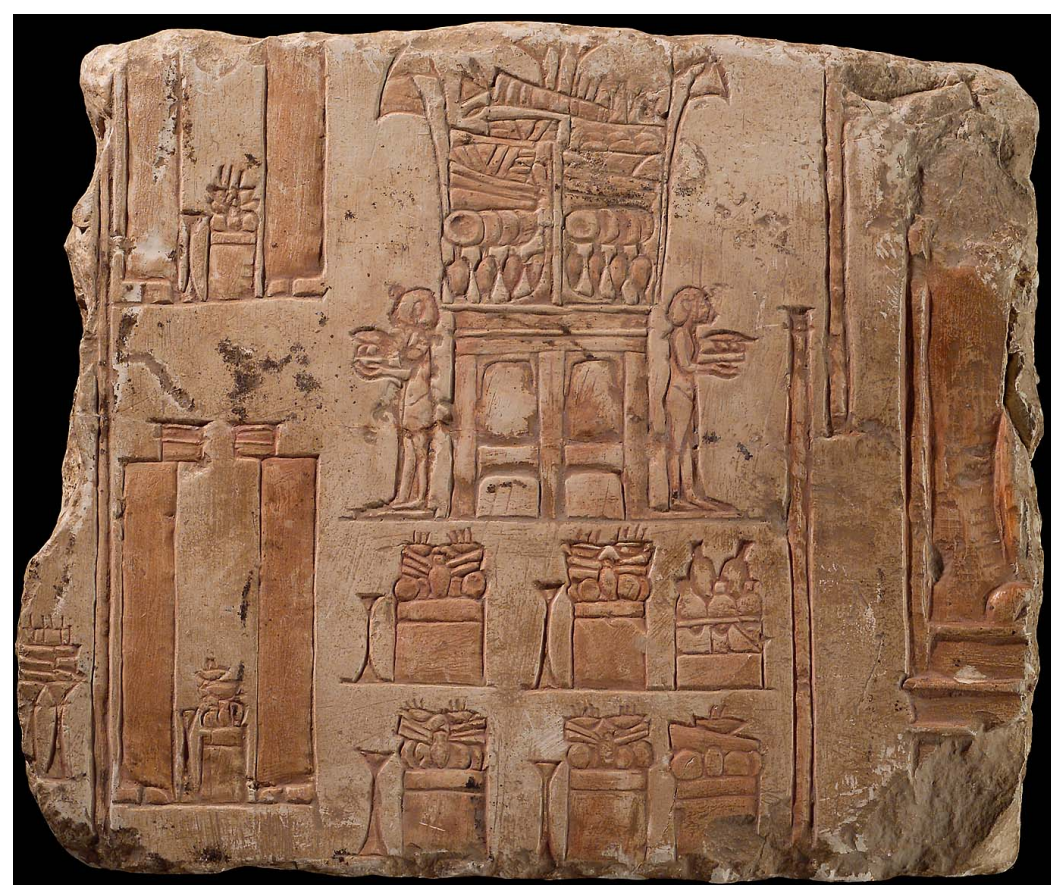

Figure 14. Talatat representing offerings in the Sanctuary of the Great Aten Temple (www.mfa.org) 
In both of these depicted scenes, statues of Akhenaten are shown holding an offering table, with very little evidence of a tall back pillar. In addition, figure 15 clearly has him wearing the khat headdress. Both scenes were correctly identified by Davies [Davies 1905:Pl. 11], Cooney [Cooney 1965:100-101] and Aldred [Aldred 1973:155] as depicting the innermost shrine of the Sanctuary temple. This not only allows locating the original position of the statue in the Sanctuary of the Great Temple, but also helps us to solve the question surrounding the headdress sported by Akhenaten.

The wide sloping of the back pillar, which starts halfway up the back of the torso and seems to end at the upper neck, points towards the khat crown as being the most likely candidate for the headdress. Cooney's description of the feature as a "braid" seems to be a bit misleading as there is no attempt by the sculptor to show waves or any lines that could be associated with a hairstyle. The feature is smooth and widens slightly to meet the back pillar. The second most likely alternativethe Blue crown-does not include a wide braid, adds a substantial weight which is usually supported by the extension of the back pillar all the way to the crown or the neck (Fig. 15).

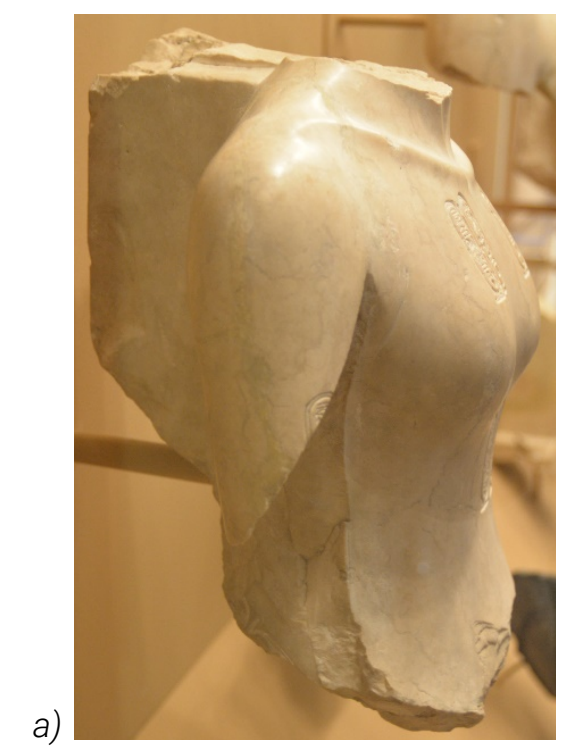

b)

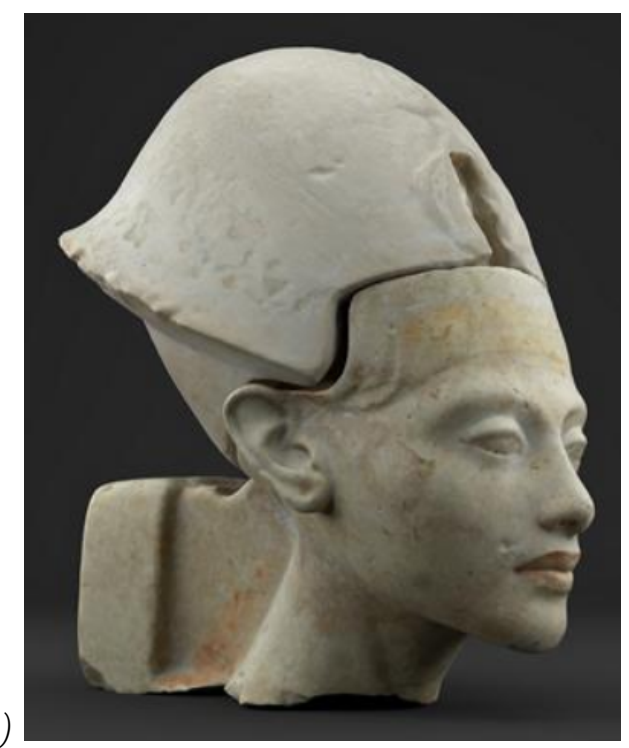

Figure 15. Akhenaten representations: a) Torso of Akhenaten in Metropolitan Museum of Art (photo by the author); b) Composite statue of Akhenaten and Blue crown in the Museum August Kestner (courtesy of Formwerk 3D).

The only other headdress that would seem plausible would be the rare khat crown favored by Akhenaten. Although representations of the khat headdress are scarce, they become more prominent during the onset of the Amarna period and last for a short time thereafter [Eaton-Krauss 1977]. It is worn mostly by royal mothers and wives, starting with Queen Hatshepsut, but quickly became popular with Akhenaten's mother, Queen Tiye, and his wife, Nefertiti. Manniche and EatonKrauss interpreted Akhenaten's decision to frequently portray himself wearing the khat crown to be symbolic of his dominion over day and night. For example, Eaton-Krauss viewed the two guardian statues of Tutankhamun, one wearing the Nemes, the other the khat as representative of the sun and 
the moon respectively [Eaton-Krauss 1977:25]. Manniche alluded to the same iconography being behind representations of colossi wearing a combination of the double crown and khat crown in Fig. 16 [Manniche 2000:110].
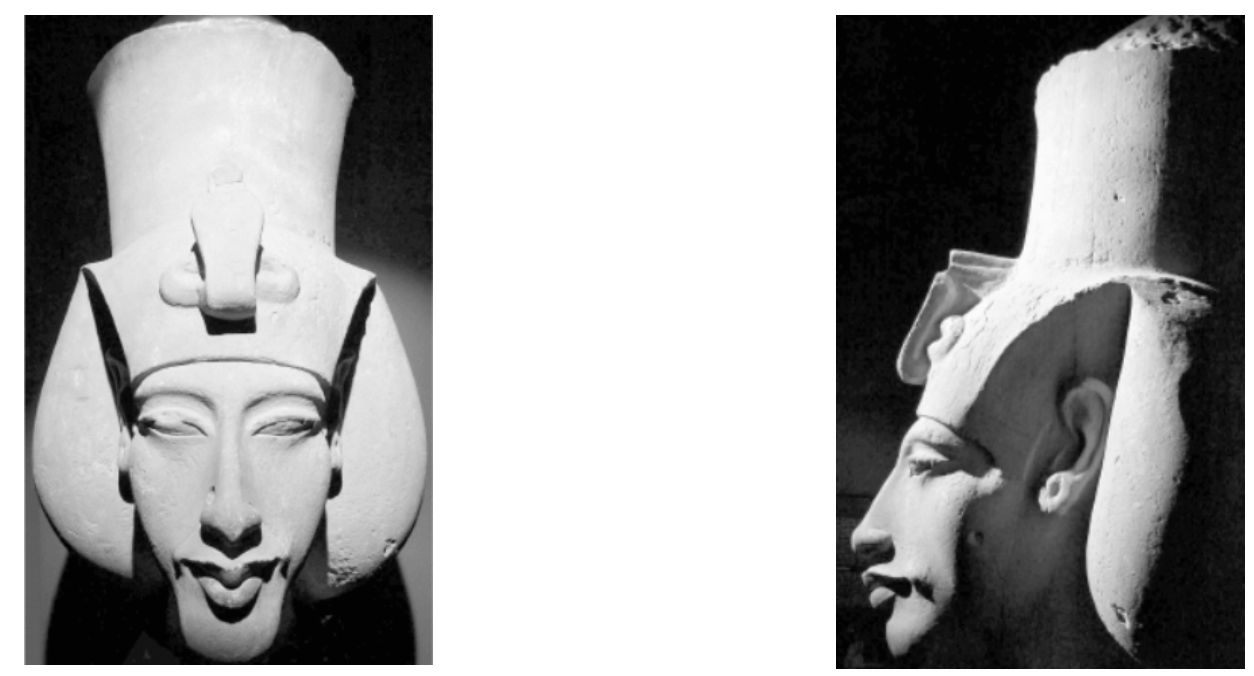

Figure 16. Akhenaten colossus wearing the khat crown in the Alexandria National Museum [Manniche 2000].

This headdress may also be attributed to Akhenaten's tendencies to depict his duality and show himself with both male and female characteristics. The khat crown is sometimes depicted as having a flowing tail draping down on the back of the wearer (Fig. 17) and could be the explanation for the wide flaring on the back of the torso.

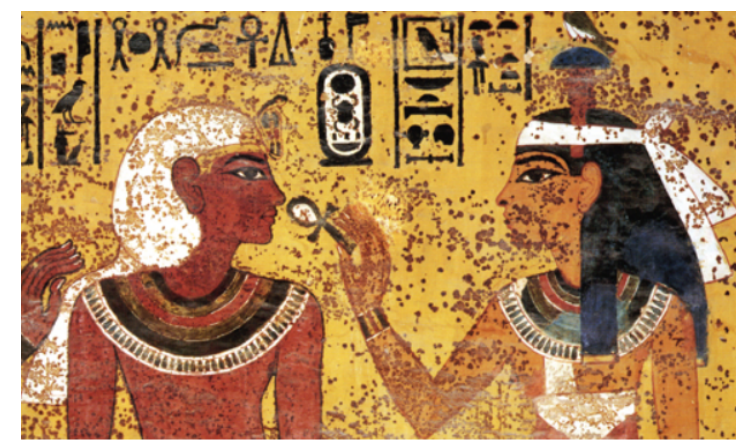

Figure 17. Tutankhamun wearing the khat crown.

Currently, the archaeological and epigraphic evidence point to the reconstruction portrayed in Figure 18 as the most likely reconstruction of the original torso. The statue represents intentional iconographical choices employed by Akhenaten and his sculptors in representing the king's relationship to this father, the Aten. This statue, like most representations of the king during the Amarna period, is a reflection of Akhenaten's intimate relationship with the god. It is further strengthened by the position of such a statue in the exclusive inner Sanctuary of the Great Temple. As a pious son, he must provide offerings to the Aten for eternity. The statue, is therefore, not only a 
symbolic image of the king doing just that, but a permanent mechanism which will ensure eternal piety.

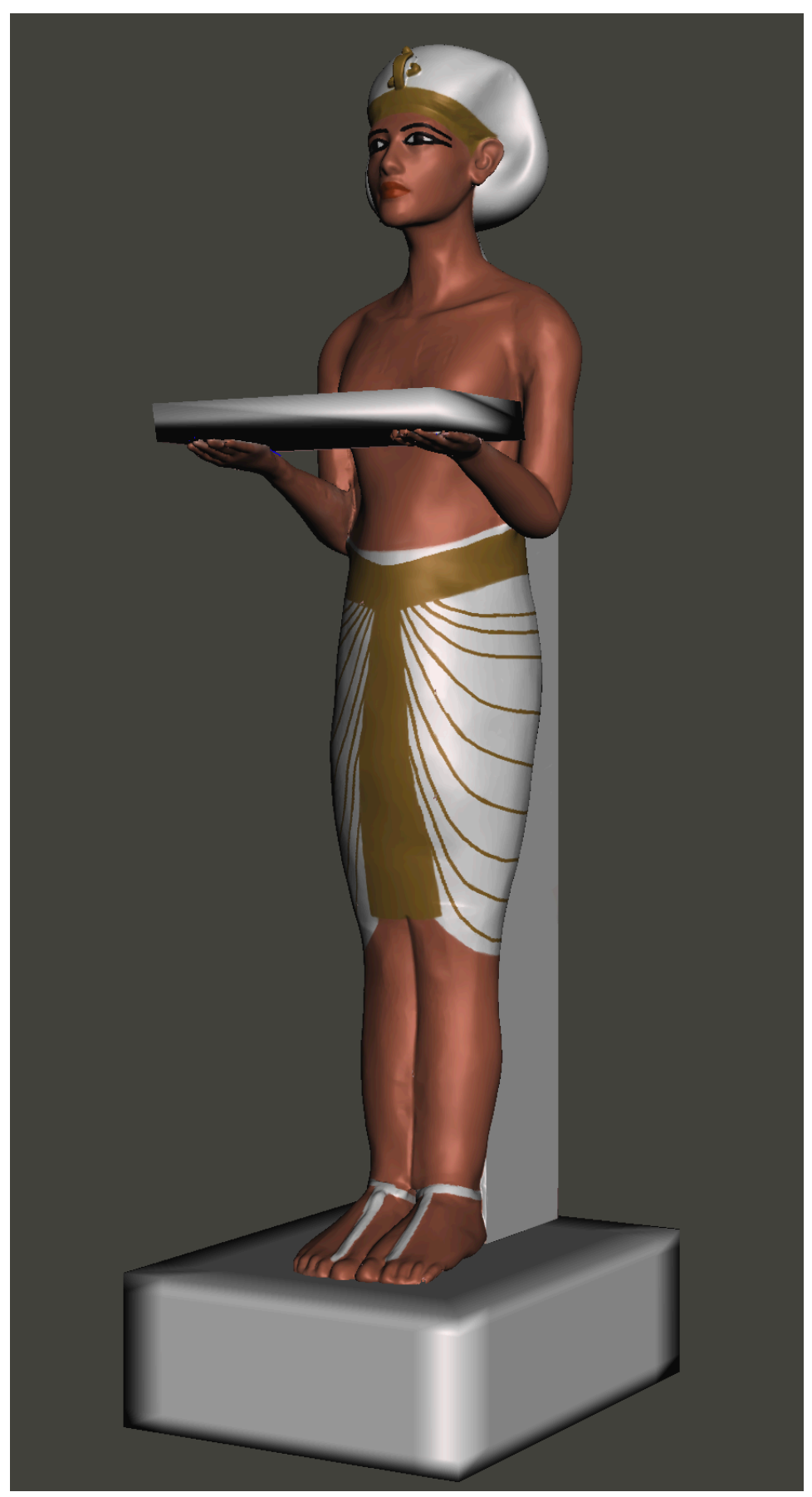

Figure 18. Reconstruction of the Brooklyn Museum torso. 


\section{METHODOLOGIES USED IN MAKING THE STATE AND RESTORATION MODELS}

The torso of Akhenaten is currently displayed in a vitrine in the Amarna Period gallery of the Brooklyn Museum. It stands on a pedestal about 1.2 meters off the ground and is lit by several overhead lights. In order to obtain a 3D rendering of the object, photogrammetry was used, a technique requiring high quality pictures of the object. Unfortunately, permission for the removal of the vitrine was not obtained, and so new methods for shooting through this optical impediment had to be devised. Dr. Gabriele Guidi ${ }^{1}$ advised a new approach to this frequently occurring obstacle present in many museums. He suggested that in order to avoid distortions caused by light refracting off the thick safety glass, photographs had to be taken at 90-degree angles, with a high overlap rate. As the camera lens had to be perpendicular to the vitrine, and the use of a tripod was crucial. As a result, the photos were shot on a Nikon D850 under adverse lighting conditions. The museum's galleries were not only lit by large, south-facing windows, but also by spotlights aimed at the torso. Fortunately, the Amarna period gallery is located a significant distance away from the large windows, and special permission was obtained to limit the artificial lighting in the room and neighboring galleries, even if some artificial lights such as emergency lights could not be turned off. In total, 74 photographs were shot in RAW format and later processed in an editing software, Adobe Lightroom to adjust the white balance and exposure. Next the photographs were imported into the photogrammetric software, Agisoft Photoscan, where they were aligned, used to create a point cloud, converted into a 3D mesh and textured (see Figure 2). Special attention was paid to photographing and modeling the cartouches, so these features could be easily read on the state model.

After creating the state model, we moved onto the restoration process in order to create a visualization of the statue's original appearance. The software package Zbrush by Pixologic was used. Akhenaten's head was added based on a 3D model rendered from Amenhotep IV/Akhenaten's Head (Fig. 16b) located in the Museum August Kestner; in Hannover. The 3D model of the head was generously provided by Erik Jagemann of Formwerk 3D and Professor Christian Loeben. The stylistic elements of the head most likely date it to the early reign of Akhenaten, possibly even to when he still called himself Amenhotep IV. The distinctive Amarna style portrait of Akhenaten's head evident in the Karnak colossi, was a gradual progression that most likely took its final form during the first couple of years at the new capital of Amarna. The Hannover head, which was most likely excavated at Hermopolis, already shows the elongated features of the neck. The head and the Blue crown it carries are detachable from one another, a fact which is beautifully illustrated in Formwerk 3D's Sketchfab clip [Formwerk 3D 2017]. However, the early date of the head does not make it the perfect candidate for the combination of the Kestner head and the Brooklyn torso. Therefore, some facial features had to be altered to match the artistic representation of the king to those of the torso. Following Aldred's discussion and in an attempt to mimic the transitional style of the Early and Late Amarna Periods, features similar to those in Figure 20 were combined with the torso and lower body producing the reconstruction in Figure 19. The belly had to be flattened and the facial features smoothed and rounded, as the post-Bek era required that Akhenaten's features be more restrained, without a prominent paunch or a slender arched neck [Aldred 1973:61-62]. The back pillar had to be entirely reconstructed in Zbrush.

\footnotetext{
${ }^{1}$ Politecnico di Milano, Italy. Visiting Scholar at IU Department of Computer Science and Informatics.
} 
a)

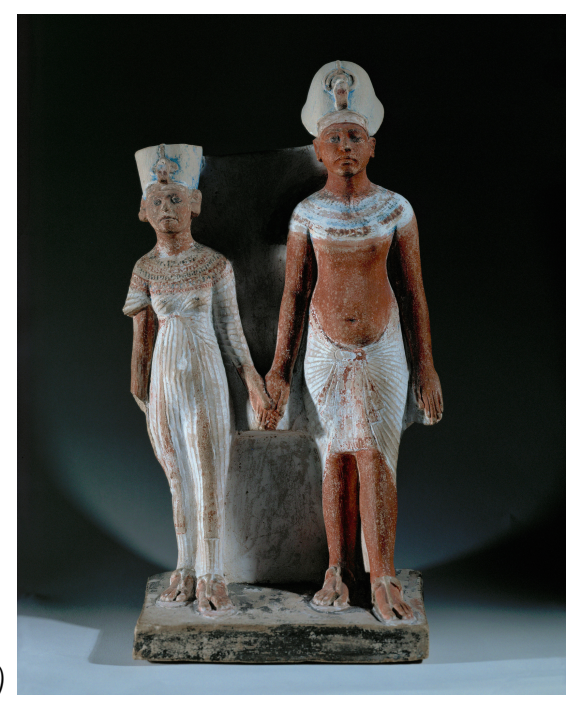

b)

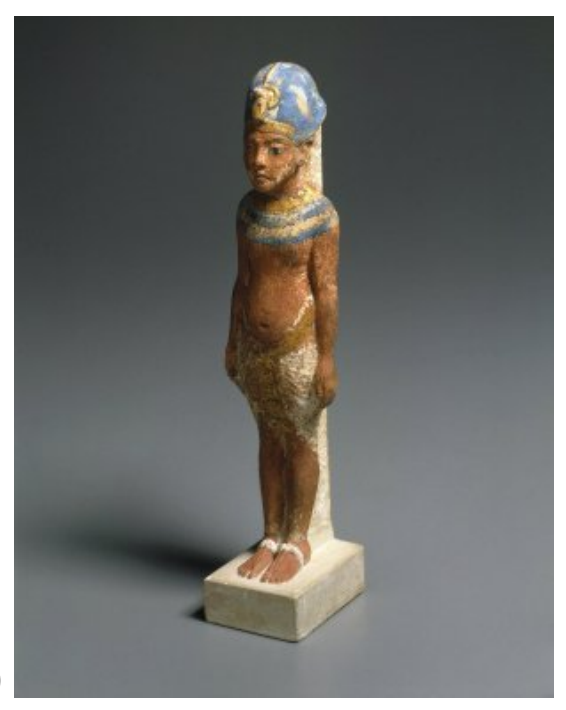

Figure 20. a) Painted limestone pair statue of Akhenaten and Nefertiti (Photo Credit: Erich Lessing / Art Resource, NY); b) Amarna King (courtesy of the Brooklyn Museum)

The reconstruction of the arms proved to be the most difficult task. Sketchfab provided a free model of an arm, courtesy of 3DHaupt [3DHaupt 2017]. The arm, however needed to be moved, resized, and repositioned into the offering-table pose. The fingers themselves had to be individually repositioned and made to appear closer together. The arm had to be meshed with the torso and head. Additionally, this part of the process required the complete rebuilding of the shoulder Next, we had to rectify the difference in polygons between the arms and the rest of the model. We had to mask the arms, cut them, and then subdivide the geometry in order to increase the polygon count. This process did not prove difficult however reattaching them, dynameshing, and maintaining the same detail on the face and crown required patient and careful maneuvering. The resulting model only needed a few touchups and polychromy. The final major decision we had to undertake was the empty space between the torso and the upper arm. The current condition of the Brooklyn torso retains more geometry on the right-hand side (see Fig. 2), indicating that the arm would have been "welded" to the body until at least the elbow. With this in mind, we reconstructed the missing geometry between the left arm and the torso. This is not only justifiable by the Egyptians' tendency to maintain structural solidarity in stone sculptures, but also their preference for maintaining symmetry. The last addition was the rectangular offering table. After time consuming, minute edits to the position of the forearms, the wrists and hands, most of our time was spent on repositioning his fingers and elusive thumbs to imitate comparable sculptures (Fig. 8). The offering table would have most likely been inscribed around the edges with Akhenaten's and Aten's names. It is very tempting to assign one of the seven offering table fragments currently located in the Metropolitan Museum of Art to our statue ${ }^{2}$. All of them were found by Petrie and Carter in 1891-1892 in a pit outside the southern wall of the Great Temple, and passed through Lord Amherst's collection, as well as Sotheby's auction house in 1921

${ }^{2}$ Metropolitan catalogue numbers: 57.180.18; 21.9.555; 57.180.99; 21.9.474; 57.180.6; 57.180.4; 21.9.553. 
[The Metropolitan Museum of Art 2018]. Besides the fact that all fragments are made of the same limestone material as the Brooklyn torso, six of them are treated in the same, indurated manner. One such fragment, figure 21, has traces of red paint present, most likely trace amounts of the skin color ${ }^{3}$.

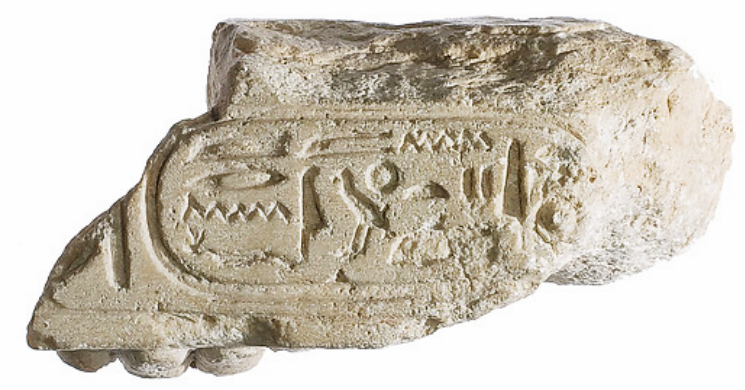

Figure 21. Hand holding offering table with Aten cartouche, MMA 57.180.6 [The Metropolitan Museum of Art 2018].

\section{POLYCHROMY}

No traces of polychromy remains on the current object, and Cooney confirmed that during his study there appeared to be no indication that the torso was painted [Cooney 1965:102]. Although no trace of color has been found on the torso, it is safe to assume the original statue would have been painted. Limestone statues were usually painted to reflect reality or specific symbolic motifs which were part of the sculpture [Baines 1985:295]. Combining evidence from the Karnak colossi and other colorful statues of Akhenaten, the model was painted. The RGB values utilized in Zbrush (and reflected in Fig. 20) were obtained by importing the picture into Photoshop and using the "eyedrop tool" in order to extract the exact RGB values (see Table 1). The same process was used for all the other colors. In an effort to get as close to the ancient hue as possible, we used hues present in Tutankhamun's tomb for the khat crown (see fig. 19), another contemporary statue of Akhenaten located in the Brooklyn Museum for the reddish skin, and the famous bust of Nefertiti for the brown-reddish color of the lips. Black was used for the makeup around the eyes and the eyebrows based on Hornung's description of the polychromy of the Karnak colossi [Hornung 1971]. The offering table was left resembling the original color of the offering table, out of cautiousness and fear of making an illogical conclusion.

Table 1. Polychromy RGB values

\begin{tabular}{|c|c|c|c|}
\hline & Red & Green & Blue \\
\hline White on crown & 254 & 254 & 254 \\
\hline Gold on crown and sash & 141 & 110 & 44 \\
\hline Skin & 169 & 96 & 7 \\
\hline Lips & 137 & 52 & 21 \\
\hline
\end{tabular}

\footnotetext{
${ }^{3}$ See figures 16 and 17 for reference.
} 


\section{CONCLUSION}

Akhenaten's upending of traditional Egyptian religious practices proved to be damaging to his reputation. The damnatio memoriae following his death destroyed most of his temples and statuary in an effort to avoid a repetition of such blasphemies in the future. Fortunately, in most cases, the destruction of royal Amarna statues also involved burying the broken pieces, preserving them for archaeologists. The torso's reconstruction not only provides a visual representation of a possible reconstruction of the original statue, but it also allows us to imagine the activities surrounding the cultic worship of the Aten. Our torso, and the original statue, stands as a quintessential example of the personal relationship that only Akhenaten, as an intermediary, had with the Aten. Its purpose was to represent the offerings of the king when he, himself, was absent. More than that, the statue's placement in the most sacred space within the Sanctuary building of the temple complex, adds to its iconographical and theological significance. The artistic propaganda instituted by Akhenaten and his sculptors during the Amarna period not only attempted to bring about a theological change, but also a cultural one. High ranking priests were stripped of their titles, the administrative capital was moved from Thebes to Amarna, and a new elite class rose to power by worshiping Akhenaten as the sun god. Art, in all shapes, inscribed, painted and sculpted, was "given birth" by Akhenaten's artists and placed in sacred spaces around Egypt in an effort to canonize and institutionalize the New Solar Theology in the cosmos. The divine and religious powers believed by the ancient Egyptians to reside within such representations of the king resulted in the careful destruction and burial of our statue outside the sacred space. In the end, the statue was not just an image of the king honoring the god but worked in conjunction with the surrounding environment and iconography as a permanent mechanism ensuring eternal devotion to the new divinity. Representations of offering scenes from the Tomb of Huya confirm such rituals and allow us to imagine its placement within the temple complex. Akhenaten, Nefertiti and their daughters, as well as servants of the Aten, would pass by our statue on a daily basis presenting their offerings to the sun god, by placing bouquets on the offering table and reciting invocations. Future work on the reconstruction of the entire temple complex, including the recontextualization of the statue in its original environment, would allow us to gain even more insight into the daily rituals of Akhenaten's Egypt.

\section{ACKNOWLEDGEMENTS}

The author gratefully acknowledges Dr. Yekaterina Barbash and Dr. Edward Bleiberg for their tremendous help, as well as providing access to the Brooklyn Museum's Egyptian, Classical, Ancient Near Eastern Art Collection.

\section{REFERENCES}

3DHaupt. "FPS-Arms". Retrieved May 24, 2019 from https://sketchfab.com/3d-models/fps-arms22274e479c794377b58671f1652f61fc

Ägyptisches Museum und Papyrussammlung der Staatlichen Museen zu Berlin - Preußischer Kulturbesitz. Standfigur Des Echnaton Mit Stele. Retrieved May 24, 2019 from http://www.smbdigital.de/eMuseumPlus?service=ExternalInterface\&module=collection\&objectId=606925\&view T 
ype=detailView

Aldred, C. 1973. Akhenaten and Nefertiti. London: Thames and Hudson.

Amarna King. Brooklyn Museum. 2018. Retrieved May 24, 2019 from https://www.brooklynmuseum.org/opencollection/objects/3305

Assmann, J. 2001. The Search for God in Ancient Egypt. Ithaca and London: Cornell University Press.

Baines J. 1985. Color Terminology and Color Classification: Ancient Egyptian Color Terminology and Polychromy. American Anthropologist. 87, 2 (1985), 287-297

Bodziony K. 2007. The Amarna Technique of Composite Sculpture. Studies in Ancient Art and Civilization.(10):1-9. Retrieved May 24, 2019 from http://www.saac.archeo.uj.edu.pl/documents/16319255/129267890/10.3.pdf/b7ac2941-45dd-472b9964-90b1923ed99a

Cooney, J. D. 1965. Amarna Reliefs from Hermopolis in American Collections. Mainz am Rhein: Verlag Philipp von Zabern.

Davies, N. de G. 1903. The Rock Tombs of El Amarna: Part I-The Tomb Meryra. London: Gilbert and Rivington Limited.

Davies, N. de G. 1905a. The Rock Tombs of El Amarna: Part II-The Tombs Panehesy and Meryra II. London: Gilbert and Rivington Limited.

Davies, N. de G. 1905b. The Rock Tombs of El Amarna: Part III-The Tombs Huya and Ahmes. London: Gilbert and Rivington Limited.

Davies, N. de G. 1908. The Rock Tombs of El Amarna: Part V-Smaller Tombs and Boundary Stela. London: William Clowes and Sons, Limited.

Eaton-Krauss, M. 1977. The "Khat" Headdress to the End of the Amarna Period. Studien zur Altaegyptischen Kultur, Bd. 5, pp. 21-39.

Formwerk 3D. Echnaton/Krone - Museum August Kestner. Retrieved May 24, 2019 from https://sketchfab.com/models/da40f11348464d78a33dc7b69b496f79

Griffith.ox.ac.uk. 1921. Catalogue of The Amherst Collection of Egyptian \& Oriental Antiquities. Retrieved May 24, 2019 from http://www.griffith.ox.ac.uk/gri/gif-files/Amherst_17.jpg

Grandorge, G. "Tour of Model." Amarna Project. Retrieved May 24, 2019 from http://www.amarnaproject.com/pages/model_of_the_city/index.shtml\#8

Hill, M. 2018a. Understanding Statuary from the Great Aten Temple. Horizon, The Amarna Project and Amarna Trust newsletter. 19 (Autumn 2018), 11-18.

Hill, M. 2018b. The Petrie-Carter Statuary Fragments from the Sanctuary Zone of the Great Aten Temple: The decoration of Amarna sacred architecture. In Marc Gabolde \& Robert Vergnieux, eds. The Buildings from the Reign of Amenhotep IV-Akhenaten: Urbanism and Revolution. Montpellier, CENiM 20: 53-85

Hornung, E. 1971. Gedanken zur Kunst der Amarnazeit. Zeitschrift fuer Aegyptische Sprache. 97, pp. 74-77.

Hornung, E. 1999. Akhenaten and the Religion of Light. Ithaca and London: Cornell University Press. James, T. G. H. 1974. Corpus of hieroglyphic inscriptions in the Brooklyn Museum. Vol. 1. New York: Brooklyn Museum.

Kemp B. and Miriam Bertram. 2018. Great Aten Temple: Report on Recent Work (Autumn 2017, Spring and Autumn 2018). Retrieved May 24, 2019 from 
http://www.amarnaproject.com/documents/pdf/GAT-report-Autumn-2017-2018-HI.pdf

Kozloff A, Bryan B, and Berman L. 1992. Egypt's Dazzling Sun. Bloomington, IN: The Cleveland Museum of Art.

Manniche, Lise. 2000. Akhenaten Colossi of Karnak. Cairo: American University in Cairo Press. Accessed October 16, 2017. ProQuest Ebook Central.

The British Museum. 2018. Retrieved May 24, 2019 from https://www.britishmuseum.org/join_in/using_digital_images/using_digital_images.aspx?asset _id=336661001\&objectId=111353\&partId=1

The Metropolitan Museum of Art. 2018. Retrieved May 24, 2019 from https://www.metmuseum.org/art/collection/search/549661

Murnane, W. J. 1995. Texts from the Amarna Period in Egypt. Atlanta: Scholars Press.

Petrie, W. M. Flinders, Archibald Henry. Sayce, Francis Llewellyn. Griffith, and Flaxman Charles John. 1894. Tell el Amarna. By W.M. Flinders Petrie. With Chapters by A.H. Sayce, F. Ll. Griffith, and F.C.J. Spurrell. London: Methuen \& Co.

Renton S. 2008. Hatshepsut's 'propaganda'(?). Electronic Egyptology Forum (EEF). Available at: http://www.egyptologyforum.org/archeef/EEFarchives.html Accessed April 1, 2018.

Robins, G. 1997. The art of ancient Egypt. London: British Museum Press for the Trustees of the British Museum.

Sambon, A. 1931. Apercu general de l'evolution de la sculpture depuis l'antiquite jusqu'a la fin du XVIe siècle. Paris. Pp. 18, pl. III.

Scott, J., and Scott. L. 1968. Egyptian Hieroglyphs for Everyone: An Introduction to the Writing of Ancient Egypt. New York.

Sethe K. 1909. Urkunde IV. Leipzig: J.C. Hinrichs'she Buchhandlung. Pp. 1971

Talatat: sanctuary of the Great Temple. Museum of Fine Arts Boston. 2018. Available at: http://www.mfa.org/collections/object/talatat-sanctuary-of-the-great-temple-46195 Accessed April 15, 2018.

Teeter, E. 2011. Religion and Ritual in Ancient Egypt. New York: Cambridge University Press.

Williams, R. C. 1930. Two Egyptian Torsos from the Main Temple of the Sun at El 'Amarneh.

Metropolitan Museum Studies, Vol. 3, No. 1 (Dec., 1930), pp. 81-99.

Wolf, W. 1957. Die Kunst Aegyptens: Gestalt und Geschichte. Stuttgart.

Received September 2018; revised April 2019; accepted May 2019. 